\title{
Haloperidol Metabolite II Valproate Ester (S)-(-)-MRJF22: Preliminary Studies as a Potential Multifunctional Agent Against Uveal Melanoma
}

Carla Barbaraci, " Giovanni Giurdanella, , Claudia Giovanna Leotta, Anna Longo, Emanuele Amata, Maria Dichiara, Lorella Pasquinucci, Rita Turnaturi, Orazio Prezzavento, Ivana Cacciatore, Elisa Zuccarello, Gabriella Lupo, Giovanni Mario Pitari,* Carmelina Daniela Anfuso,* and Agostino Marrazzo*

Cite This: J. Med. Chem. 2021, 64, 13622-13632

Read Online

ACCESS | Llll Metrics \& More | 回 Article Recommendations | sl Supporting Information

ABSTRACT: Increased angiogenesis and vascular endothelial growth factor (VEGF) levels contribute to higher metastasis and mortality in uveal melanoma (UM), an aggressive malignancy of the eye in adults. $( \pm)$-MRJF22, a prodrug of the sigma $(\sigma)$ ligand haloperidol metabolite II conjugated with the histone deacetylase (HDAC) inhibitor valproic acid, has previously demonstrated a promising antiangiogenic activity. Herein, the asymmetric synthesis of (R)-(+)-MRJF22 and (S)-(-)-MRJF22 was performed to investigate their contribution to $( \pm)$-MRJF22 antiangiogenic effects in human retinal endothelial cells (HREC) and to assess their therapeutic potential in primary human uveal melanoma (UM) 92-1 cell line. While both enantiomers displayed almost

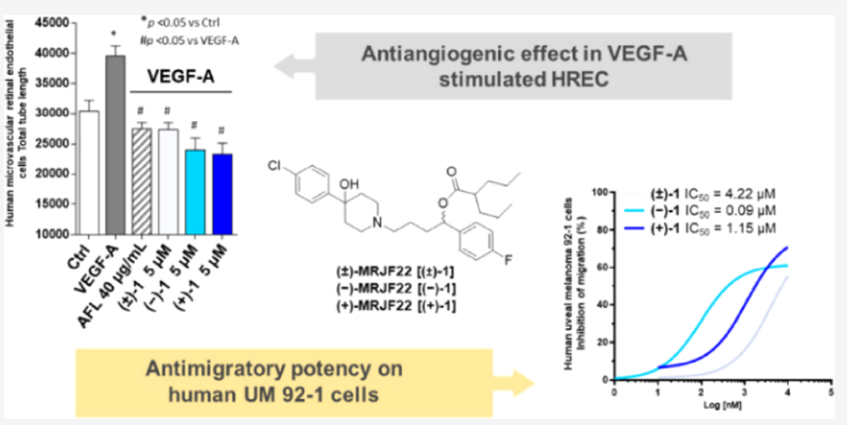
identical capabilities to reduce cell viability than the racemic mixture, (S)-(-)-MRJF22 exhibited the highest antimigratory effects in endothelial and tumor cells. Given the fundamental contribution of cell motility to cancer progression, (S)-(-)-MRJF22 may represent a promising candidate for novel antimetastatic therapy in patients with UM.

\section{INTRODUCTION}

Uveal melanoma (UM) is a rare and aggressive intraocular tumor, which arises from melanocytes such as cutaneous melanoma, but presents unique biology and genetic traits. ${ }^{1}$ Approximately $90 \%$ of all UMs involve the choroid, while the rest involve the ciliary body $(6 \%)$ or iris $(4 \%){ }^{2}$ Despite early diagnosis and treatment with conventional chemotherapy and surgery, nearly $50 \%$ of all UM patients develop hepatic metastases, which are usually fatal within 1 year from diagnosis. $^{3-5}$

Lacking an intraocular lymphatic system, UM tends to spread via a hematogenous route, and the presence of microvascular loops and networks is clinically related to UM progression and a worse prognosis. ${ }^{6}$ Recent studies have shown that different UM cell lines produce a copious amount of vascular endothelial growth factor (VEGF), the primary activator of tumor angiogenesis in mammals. ${ }^{9}$ Treatment of inoperable UM patients with the VEGF-trap aflibercept (AFL), a popular drug in ophthalmology, resulted in 50\% progressionfree survival at 4 months. $^{7-9}$ Intravitreal injection of bevacizumab, an antiangiogenic monoclonal antibody targeting all isoforms of vascular endothelial growth factor A (VEGF-A), is currently under evaluation through a phase II trial for the treatment of UM metastatic disease. ${ }^{10-12}$

Sigma $(\sigma)$ receptors are involved in different biological functions, including cell proliferation and survival, and are overexpressed in several tumor cell lines. ${ }^{13}$ This unique class of receptors consists of two subtypes, sigma-1 $\left(\sigma_{1}\right)$ and sigma-2 $\left(\sigma_{2}\right)$. The $\sigma_{1}$ receptor is a chaperon protein at the mitochondria-associated membrane (MAM) involved in apoptosis, and its in vivo silencing modulates endothelial cell proliferation and inhibits angiogenesis. ${ }^{14}$ The presence of the $\sigma_{1}$ receptor in cancer cells increases VEGF secretion and stimulates motility, in part through the regulation of the human voltage-dependent $\mathrm{K}^{+}$channel (hERG) membrane expression. ${ }^{15}$ Recently identified as the ER-resident transmembrane protein 97 (TMEM97), the $\sigma_{2}$ receptor is poorly understood. ${ }^{16}$ Recognized as a biomarker of cell proliferation,

Received: June 2, 2021

Published: September 3, 2021 


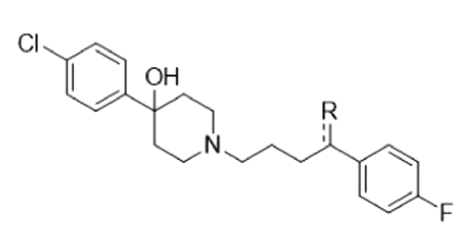

Haloperidol (HP) R = O

Haloperidol metabolite II (HP-mll) $\mathrm{R}=\mathrm{OH}$

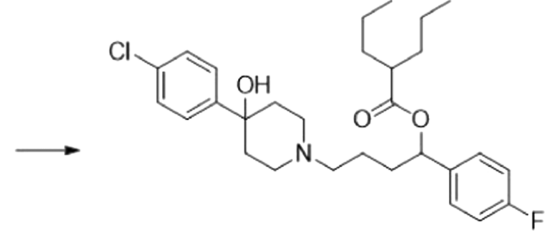

(士)-MRJF22 [(士)-1]

Figure 1. Chemical structure of HP, HP-mII, and ( \pm )-MRJF22.

Scheme 1. Enantioselective Synthesis for Compounds (+)-1 and (-)-1 ${ }^{a}$
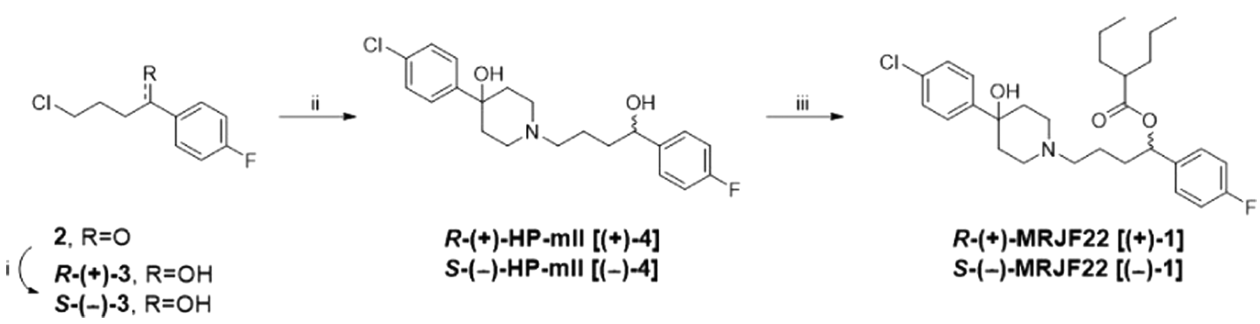

${ }^{a}$ Reagents and conditions: (i) (+)- or (-)-DIP-Cl, tetrahydrofuran (THF), $-25{ }^{\circ} \mathrm{C}, 16 \mathrm{~h}$; DEA, $\mathrm{Et}_{2} \mathrm{O}$, room temperature (rt), on; (ii) 4-(4chlorophenyl)hydroxypiperidine, $\mathrm{KHCO}_{3}$, anhydrous dimethylformamide (DMF), $80{ }^{\circ} \mathrm{C}, 24 \mathrm{~h}$; (iii) 2-propylpentanoyl chloride, $\mathrm{THF}, 0{ }^{\circ} \mathrm{C}$ to $\mathrm{rt}, 3$ h.

the mechanism by which the $\sigma_{2}$ receptor promotes apoptosis and autophagy remains unclear. ${ }^{17,18}$ Data suggest that $\sigma$ receptors are able to induce apoptosis and autophagy in UM, whereas they mediate opposite biological effects on cell proliferation. ${ }^{19,20}$ Notably, compounds endowed with a $\sigma_{1}$ receptor antagonists $/ \sigma_{2}$ receptor agonist functional profile such as haloperidol (HP) and haloperidol metabolite II (HP$\mathrm{mII}$ ) have been shown to reduce human UM cell proliferation. Different from HP-mII, which displays a preferential activity for $\sigma$ receptors compared to other receptor systems, antiproliferation by HP on UM 92-1 cells may be due to additional nonspecific effects. ${ }^{20,21}$

Histone deacetylases (HDACs) are enzymes involved in specific epigenetic changes associated with cancer and other diseases. $^{22}$ Inhibition of HDACs induces hyperacetylation of histones, which affects gene expression. ${ }^{23}$ HDAC inhibitors (HDACis) induce the inhibition of angiogenesis through various mechanisms, such as activation of cell-cycle arrest or induction of apoptosis and autophagy..$^{22,24,25}$ More than 20 HDACis have entered clinical studies, with vorinostat and romidepsin approved for the treatment of cutaneous $\mathrm{T}$-cell lymphoma. ${ }^{26,27}$ HDACi may play a role in the adjuvant therapy of patients with UM by inducing differentiation and prolonged dormancy of micrometastases. ${ }^{28}$ In this context, HDACi valproic acid (VPA) induces G1 cell-cycle arrest of UM cells and reduces UM progression in vivo and has recently undergone a phase II clinical trial for high-risk UM patients. $^{29-31}$

To improve antiangiogenic and anticancer capabilities, dual ligands targeting $\sigma$ receptors and HDAC were previously developed employing a prodrug approach. ${ }^{32,33}( \pm)$-MRJF22 $[( \pm)-1]$, a prodrug of $( \pm)-\mathrm{HP}-\mathrm{mII}$ with VPA (Figure 1 ), significantly reduced cell migration and proliferation (20 and 120 times more than ( \pm )-HP-mII and VPA, respectively) in VEGF-A-stimulated human retinal endothelial cells (HRECs). ${ }^{34}$

Angiogenesis within UM progression is the result of a complex interplay between endothelial and tumor cells, in which VEGF-A may play a significant role. ${ }^{35,36}$ The involvement of $\sigma$ receptors and HDAC in antiangiogenic and antiproliferative activities makes the prodrug $( \pm)-1$ a potential pharmacological tool exploitable for the treatment of UM metastatic disease. To gain more insights and define contribution to antiangiogenic effects by $( \pm)-\mathbf{1}$, the asymmetric synthesis of (R)-(+)-MRJF22 $[(+)-1]$ and (S)$(-)$-MRJF22 [(-)-1] and their evaluation on VEGF-Astimulated HRECs is described here. Moreover, present studies investigate the effects of $( \pm)-1$ and its enantiomers on human UM 92-1 cell proliferation and migration, which together with angiogenesis represents the principal determinants of metastasis development in UM.

\section{RESULTS AND DISCUSSION}

Chemistry. Synthesis of (+)-1 and (-)-1 was achieved through enantioselective reduction, as reported in the literature. ${ }^{33,37}$ According to the steps in Scheme 1, the commercially available 4-chloro-1-(4-fluorophenyl)butan-1one (2) was treated with the reductive agents $(+)$ or (-)-diisopinocampheylchloroborane (DIP-Cl), allowing a highly stereoselective reaction. Afterward, diethanolamine (DEA) was added, and the intermediates (+)-3 and (-)-3 were used for the synthesis of compounds $(R)-(+)-$ HP-mII $[(+)-4]$ and $(S)-(-)$-HP-mII $[(-)-4]$ by nucleophilic substitution on the nitrogen of the amine 4-(4-chlorophenyl)hydroxypiperidine. The 2-propylpentanoyl chloride was allowed to react with compounds (+)-4 and (-)-4, giving compounds (+)-1 and (-)-1. ${ }^{34}$

The optical rotation for both enantiomers was determined in $\mathrm{CHCl}_{3}$ solution to afford $(+)-1[\alpha]_{\mathrm{D}}^{20}=+24.8^{\circ}\left(c 1.0, \mathrm{CHCl}_{3}\right)$ and $(-)-1[\alpha]_{\mathrm{D}}^{20}=-26.0^{\circ}\left(c 1.0, \mathrm{CHCl}_{3}\right)$.

Enantiomeric excess (ee) was calculated to measure the purity of the synthesized compound by high-performance liquid chromatography (HPLC) analyses using a Chiralcel $\mathrm{OJ}[-\mathrm{RH}]$ column. Both enantiomers were obtained enantiomerically pure, showing an ee equal to 92 and $95.4 \%$ for $(+)-1$ and $(-)-1$, respectively (Figure S1, Supporting Information). 
Table 1. Chemical and Enzymatic Stabilities of ( \pm )-1 and Its Two Enantiomers

\begin{tabular}{|c|c|c|c|c|c|c|c|}
\hline \multirow{2}{*}{\multicolumn{2}{|c|}{ stability }} & \multicolumn{2}{|c|}{$( \pm)-1$} & \multicolumn{2}{|c|}{$(+)-1$} & \multicolumn{2}{|c|}{$(-)-1$} \\
\hline & & $t_{1 / 2}(\mathrm{~h})$ & $K_{\text {obs }}\left(\mathrm{h}^{-1}\right)$ & $t_{1 / 2}(\mathrm{~h})$ & $K_{\text {obs }}\left(h^{-1}\right)$ & $t_{1 / 2}(\mathrm{~h})$ & $K_{\text {obs }}\left(h^{-1}\right)$ \\
\hline \multirow[t]{2}{*}{ chemical $^{a}$} & pH 1.3 & $100.1 \pm 3.1$ & $0.007 \pm 0.001$ & & & & \\
\hline & pH 7.4 & $96.4 \pm 1.6$ & $0.007 \pm 0.001$ & & & & \\
\hline \multirow[t]{2}{*}{ enzymatic $^{a}$} & human plasma & $60.5 \pm 0.6$ & $0.011 \pm 0.006$ & $58.2 \pm 1.2$ & $0.012 \pm 0.001$ & $70.3 \pm 1.5$ & $0.01 \pm 0.002$ \\
\hline & rat plasma & $0.234 \pm 0.003$ & $2.96 \pm 0.01$ & $0.434 \pm 0.002$ & $1.60 \pm 0.005$ & $0.322 \pm 0.01$ & $2.15 \pm 0.03$ \\
\hline
\end{tabular}

${ }^{a}$ Values are means \pm standard deviation $(\mathrm{SD})$ of three experiments.

Chemical and Enzymatic Stability. The chemical stability of $( \pm)-1$ was evaluated in buffer solutions at $\mathrm{pH} 1.3$ and 7.4 (Table 1). The results showed that the racemate was stable for about 4 days in both environments.

Enzymatic stability studies in rat and human plasma were performed for both the racemate and its enantiomers (Table 1 ). As we expected, the compounds were rapidly hydrolyzed by carboxylesterases present in rat plasma $\left(t_{1 / 2}, 0.2-0.4 \mathrm{~h}\right.$ ) compared to human plasma $\left(t_{1 / 2},>58 \mathrm{~h}\right)$ due to the huge disparity between the esterase content in both plasma. ${ }^{38}$ Considering the high stability of $( \pm)-1$ and its enantiomers in simulated physiological fluids and human plasma, these compounds could reach the target site without undergoing esterase metabolism.

Sigma Receptor Binding Assay. To examine the effects of asymmetric synthesis on $\sigma$ receptor occupancy, $\sigma_{1}$ and $\sigma_{2}$ receptor affinities for $(+)-1$ and $(-)-1$ were measured and compared to precursors (+)-4 and (-)-4 and their respective racemic mixtures (Table 2 ).

Table 2. $\sigma_{1}$ and $\sigma_{2}$ Binding Assays for Compound ( \pm )-1, Its Enantiomers, and Precursor Compounds

\begin{tabular}{lcc} 
& \multicolumn{2}{c}{$K_{\mathrm{i}} \pm \mathrm{SD}(\mathrm{nM})^{a}$} \\
\cline { 2 - 3 }$( \pm)-\mathbf{1}^{b}$ & $\sigma_{1}$ & $\sigma_{2}$ \\
$(+)-1$ & $13 \pm 0.6$ & $124 \pm 15$ \\
$(-)-1$ & $64 \pm 8.2$ & $74 \pm 8.9$ \\
$( \pm)-\mathrm{HP}^{b}-\mathrm{mII}^{b}$ & $16 \pm 1.7$ & $56 \pm 6.4$ \\
$(+)-4^{b}$ & $2.9 \pm 1.1$ & $2.4 \pm 0.7$ \\
$(-)-4^{b}$ & $2.0 \pm 0.6$ & $32 \pm 2.8$ \\
$\mathrm{HP}^{b}$ & $3.0 \pm 1.1$ & $9.8 \pm 1.8$ \\
& $2.7 \pm 0.7$ & $17 \pm 0.7$
\end{tabular}

${ }^{a}$ Each value is the mean \pm SD of at least two experiments performed in duplicate. ${ }^{b}$ Data taken from ref 34 .

The esterification of the secondary hydroxy group of (+)-4 and (-)-4 with VPA decreased the binding affinity of $\sigma$ receptors compared to ( \pm )-HP-mII, confirming previous observations with $( \pm)-1 .{ }^{34}$ Distinctive differences emerged for the enantiomer binding profiles at $\sigma$ receptors. The $\sigma_{1}$ binding affinity of the (-)-enantiomer $\left(K_{\mathrm{i}}=16 \mathrm{nM}\right)$ was similar to that of $( \pm)-1\left(K_{\mathrm{i}}=13 \mathrm{nM}\right)$ but higher than that of the $(+)$-stereoisomer $\left(K_{\mathrm{i}}=64 \mathrm{nM}\right)$. Both enantiomers 1 exhibited higher affinities for $\sigma_{2}$ receptors than the racemic mixture $( \pm)-1$ with a $K_{\mathrm{i}}$ value of $56 \mathrm{nM}$ for $(-)-1$ and $74 \mathrm{nM}$ for (+)-1. In contrast, their precursors (+)-4 and (-)-4 exhibited lower affinities for $\sigma_{2}$ receptors than $( \pm)$-HP-mII, probably due to positive allosteric modulations of the two enantiomers for $\sigma$ receptors. ${ }^{39}$ The superior binding affinity of the (-)-1 enantiomer on the $\sigma_{2}$ receptor probably reflects favorable molecular interactions by the precursor (-)-4 with respect to the $(+)$-enantiomer or HP.
Antiangiogenic Activity on HREC. To dissect enantiomer contributions to antiangiogenic effects by $( \pm)-1$, compounds (+)-1 and (-)-1 were evaluated on HREC, an endothelial cell model of angiogenesis. ${ }^{40}$ First, HREC viability was assessed by the 3-[4,5-dimethylthiazol-2-yl]-2,5-diphenyltetrazolium bromide (MTT) assay to verify the tolerability of the enantiomers, and different concentrations (1.0, 2.5, 5.0, 10.0 , and $20.0 \mu \mathrm{M})$ of the compounds were tested for 24,48 , and $72 \mathrm{~h}$. The $\mathrm{IC}_{50}$ values of (+)-1 and (-)-1 were calculated and compared to $( \pm)-1$ and its precursors (Table 3 ).

Table 3. IC $_{50}$ Obtained by the MTT Viability Test on HREC at Different Time Points for Compounds (+)-1 and (-)-1 and Their Precursors

$\begin{array}{cccc}\text { cmpd } & \text { time }(\mathrm{h}) & \mathrm{IC}_{50}(\mu \mathrm{M})^{a} & \mathrm{pIC}_{50} \pm \mathrm{SE}^{b} \\ ( \pm)-\mathbf{1}^{c} & 24 & 10.5 & 4.98 \pm 0.02 \\ & 48 & 11.1 & 4.95 \pm 0.03 \\ (+)-1 & 72 & 10.1 & 4.99 \pm 0.04 \\ & 24 & 9.8 & 5.01 \pm 0.03 \\ (-)-1 & 48 & 6.4 & 5.19 \pm 0.01 \\ & 72 & 4.4 & 5.35 \pm 0.01 \\ & 24 & 10.1 & 4.97 \pm 0.07 \\ \mathrm{VPA}^{c} & 48 & 9.0 & 5.04 \pm 0.01 \\ & 72 & 6.8 & 5.16 \pm 0.42 \\ & 24 & 1217 & 2.91 \pm 0.01 \\ ( \pm)-\mathrm{HP}-\mathrm{mII} & 48 & 1449 & 2.84 \pm 0.03 \\ & 72 & 1393 & 2.86 \pm 0.01 \\ & 24 & >200^{d} & \\ \mathrm{HP}^{c} & 48 & 128 & 3.89 \pm 0.04 \\ & 72 & 69 & 4.16 \pm 0.03 \\ & 24 & 3.7 & 5.43 \pm 0.04 \\ & 48 & 2.9 & 5.54 \pm 0.08 \\ & 72 & 2.6 & 5.59 \pm 0.07\end{array}$

${ }^{a} \mathrm{IC}_{50}$ values have been calculated with GraphPad Prism 5 for Windows using a nonlinear fit transform sigmoidal dose-response (variable slope). $\mathrm{IC}_{50}$ values are averaged from multiple determinations $\left(n=3\right.$, each of them). ${ }^{b} \mathrm{pIC}_{50}$ is defined as the $-\log \left(\mathrm{IC}_{50}\right)$. ${ }^{c}$ Data taken from ref $34 .{ }^{d}$ Cell viability reduction lower than $50 \%$ at $200 \mu \mathrm{M}$.

At $24 \mathrm{~h}$, the enantiomers showed similar extent and efficacy in reducing HREC cell viability compared to the racemic mixture $( \pm)-1$ but, contrary to this, reduced the cell viability in a time-dependent manner (Figure S2). Indeed, the $\mathrm{IC}_{50}$ ranged from 9.8 to $4.4 \mu \mathrm{M}$ for $(+)-1$ and from 10.1 to $6.8 \mu \mathrm{M}$ for $(-)-1$, not significantly different from those of $( \pm)-\mathbf{1}$ (from 10.5 to $10.1 \mu \mathrm{M})$. Moreover, confirming previous results with $( \pm)-1,{ }^{34}$ both enantiomers exhibited higher antiproliferative potencies in HREC with respect to precursors VPA and (士)-HP-mII (Table 3). In contrast, HP remains the most potent compound in reducing HREC viability, compared to (土)-1 and its enantiomers (Table 3). ${ }^{34}$ The results suggest 
that the enantiomers exert a toxicity comparable to that of the racemic mixture on HREC and, in any case, more tolerated by the cells than their precursor HP.

To investigate the ability of $( \pm)-1,(+)-1$, and $(-)-1$ to counteract the VEGF-A proangiogenic effect, crystal violet assays were carried out to evaluate cell proliferation in HREC stimulated with $80 \mathrm{ng} / \mathrm{mL}$ VEGF-A (Figure 2). As expected,

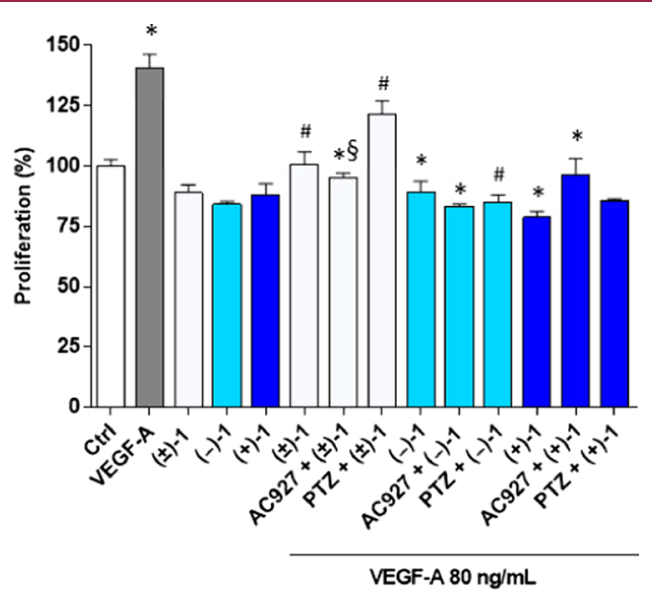

Figure 2. Antiproliferative effects of $( \pm)-1,(+)-1$, and (-)-1 in HREC stimulated with VEGF-A, assessed by the crystal violet assay. HREC were treated with $5 \mu \mathrm{M}( \pm)-1,(+)-1$, and (-)-1 in the presence or absence of $80 \mathrm{ng} / \mathrm{mL}$ VEGF-A for $24 \mathrm{~h}$. Effects of the $\sigma_{2}$ receptor antagonist $\mathrm{AC} 927(2 \mu \mathrm{M})$ and the selective $\sigma_{1}$ receptor agonist $(+)$-pentazocine (PTZ) $(2 \mu \mathrm{M})$ in HREC cotreated with 5 $\mu \mathrm{M}( \pm)-1$ or (+)-1 and (-)-1 $80 \mathrm{ng} / \mathrm{mL}$ of VEGF-A for $24 \mathrm{~h}$. Ctrl, vehicle control (dimethyl sulfoxide, DMSO). Data are expressed as a percentage of proliferation with respect to vehicle control. ${ }^{*} p<0.05$ vs Ctrl; ${ }_{p}^{\#}<0.05$ vs VEGF-A; $\$_{p}<0.05$ vs the same conditions without agonist or antagonist.

VEGF-A exerted a proangiogenic effect by increasing cell proliferation by about $45 \%$ (at $24 \mathrm{~h}$ ) with respect to the untreated control (Figure 2). Under basal conditions, treatments with $5 \mu \mathrm{M}( \pm)-1,(+)-1$, and (-)-1 did not induce significant changes in HREC proliferation rates after $24 \mathrm{~h}$ (Figure 2). In contrast, equimolar concentrations $(5 \mu \mathrm{M})$ of $( \pm)-1,(+)-1$, and (-)-1 completely prevented VEGF-Amediated HREC proliferation (Figure 2). These data are in agreement with previous reports obtained with $( \pm)-1$, which demonstrated that this prodrug exhibits peculiar antiangiogenetic effects comparable to bevacizumab that are not shared with the precursors VPA and ( \pm )-HP-mII. ${ }^{34}$

To evaluate the role of $\sigma$ receptors in prodrug-mediated inhibition of VEGF-A-stimulated HREC proliferation, $( \pm)-1$ and its enantiomers were examined in combination with the $\sigma_{1}$ receptor agonist $(+)$-pentazocine $[\mathrm{PTZ}, 2 \mu \mathrm{M}]$ and the $\sigma_{2}$ receptor antagonist 1-phenethylpiperidine (AC927, $2 \mu \mathrm{M}$ ).

Confirming previous results, ${ }^{34}$ PTZ partially counteracted the anti-VEGF-A activity of the $( \pm)$-1 racemic mixture (Figure 2 ), suggesting that $( \pm)-1$ may function, at least in part, as a $\sigma_{1}$ antagonist in the inhibition of VEGF-A-stimulated HREC proliferation. Surprisingly, coincubations with PTZ or AC927 did not alter the anti-VEGF-A effects on proliferation by (+)-1 and (-)-1 (Figure 2), ruling out a relevant role of $\sigma$ receptor in antiangiogenetic effects by the prodrugs with respect to VEGFA-mediated HREC proliferation. Presumably, a minimal contribution of $\sigma_{1}$ receptors to racemic mixture effects (Figure
2 ) could reflect differences in overall affinities toward $\sigma_{1}$ and $\sigma_{2}$ receptors compared to the single enantiomer components.

Unregulated stimulation of endothelial cell motility by VEGF-A underlies pathological angiogenesis. ${ }^{41}$ Therefore, the effects of $( \pm)-1,(+)-1$, and (-)-1 on HREC motility stimulated by VEGF-A $(80 \mathrm{ng} / \mathrm{mL})$ were evaluated with the wound healing assays (Figures 3 and S3-S5). VEGF-A promoted HREC migration compared to untreated controls, inducing complete wound closures at $24 \mathrm{~h}$ (Figures S3-S5). In contrast, HREC monolayers did not close their wounds over $48 \mathrm{~h}$ incubation in the presence of $5 \mu \mathrm{M}( \pm)-1$ or its enantiomers (Figure $3 \mathrm{~A}-\mathrm{C}$ ). Of note, while HREC monolayers did not significantly alter wound changes in unstimulated cells, the three prodrugs completely abrogated VEGF-Amediated induction of HREC migration (Figure $3 \mathrm{~A}-\mathrm{C}$ ). Cotreatments with both AC927 and PTZ reduced ( \pm )-1 and (+)-1 abilities to inhibit VEGF-A-mediated wound healing (Figure 3A,B). However, while PTZ or AC927 exhibited similar actions with ( \pm )-1 and significantly, but partially, opposed the inhibition of VEGF-A-mediated cell motility by the racemic mixture (Figure 3A), (+)-1 effects were significantly and completely blocked only by (+)-PTZ coincubation (Figure 3B). Distinctively, the inhibition of VEGF-A-mediated HREC motility by $(-)-1$ was prevented, in part, only by cotreatment with the $\sigma_{2}$ receptor antagonist AC927 (Figure 3C). These data suggest a plausible involvement of both $\sigma_{1}$ and $\sigma_{2}$ receptors in the regulation of VEGF-A-mediated HREC motility by the racemic mixture, reflecting the contribution of $\sigma_{1}$ and $\sigma_{2}$ receptor regulation by enantiomer (+)-1 and enantiomer (-)-1, respectively. Moreover, compared to the other prodrugs, enantiomer (-)-1 produced the highest reduction of HREC motility stimulated by VEGF-A (Figure $3 \mathrm{~A}-\mathrm{C}$ ), below the basal levels of the untreated control (Figure 3C). Since (-)-1 has the greatest $\sigma_{2}$ binding affinity of the dual-ligand prodrugs (Table 2 ), these results suggest that $\sigma$ receptor-mediated regulation of HREC migration by VEGF-A is principally sensitive to $\sigma_{2}$ agonist activity. The representative images of HREC treated with VEGF-A and three prodrug derivatives after the scratch wound are shown in the Supporting Information (Figures S2-S4A).

To further explore effects on angiogenesis, tube formation assays with HREC were evaluated. Following seeding onto basement membranelike Matrigel and stimulation for $24 \mathrm{~h}$ with VEGF-A ( $80 \mathrm{ng} / \mathrm{mL})$, HREC organized into networks of tubular structures mimicking capillary formation in neoangiogenesis (Figure 4A). As expected, VEGF-A significantly increased total tube length by HREC, an effect prevented by cotreatment with VEGF-trap AFL (Figure 4B). Treatments with $( \pm)-1,(+)-1$, or $(-)-1$ also blocked VEGF-A-stimulated tube formation in HREC, with effects similar to those of AFL (Figure 4B). In close agreement with findings in HREC motility (Figure 3 ), while $( \pm)-1$ actions on VEGF-Astimulated tube formation were partially and equally blocked by both $\sigma_{1}$ receptor agonist PTZ and $\sigma_{2}$ receptor antagonist AC927, (+)-1 and (-)-1 effects were prevented selectively by AC927 and PTZ, respectively (Figure 4B). Again, these results suggest the simultaneous involvement of $\sigma_{1}$ and $\sigma_{2}$ receptors in the regulation of VEGF-A-induced HREC tube formation by the racemic mixture, reflecting the selective contribution of the $\sigma_{1}$ receptor antagonism by enantiomer $(+)-1$ and the $\sigma_{2}$ receptor agonism by enantiomer (-)-1.

Overall, ( \pm )-1 and its enantiomers exhibit significant but distinct antiangiogenic effects as assessed with the HREC 
A

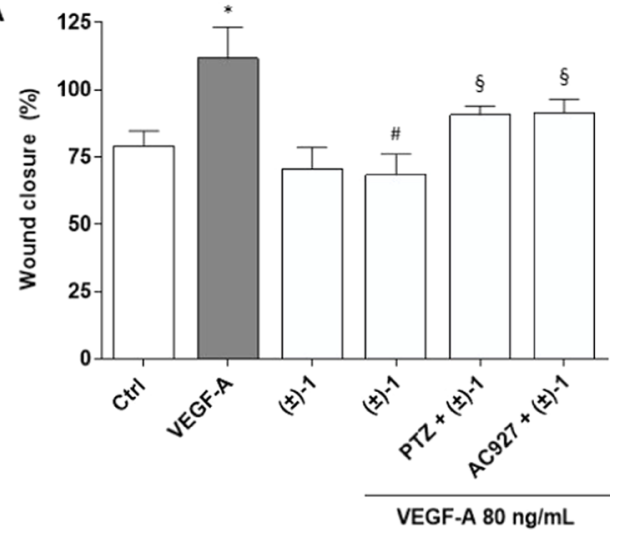

B

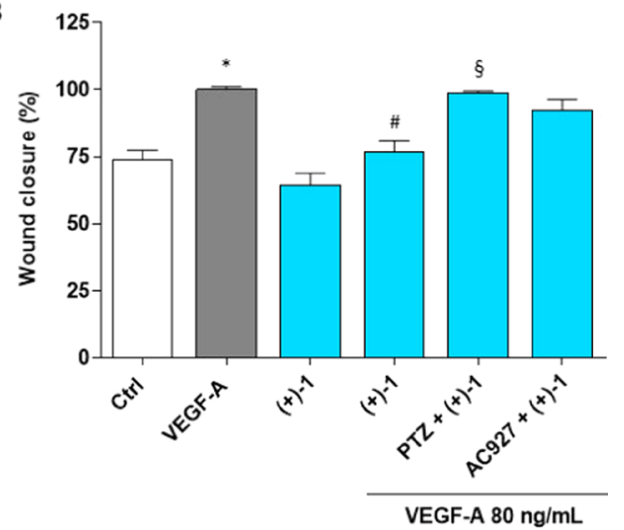

C

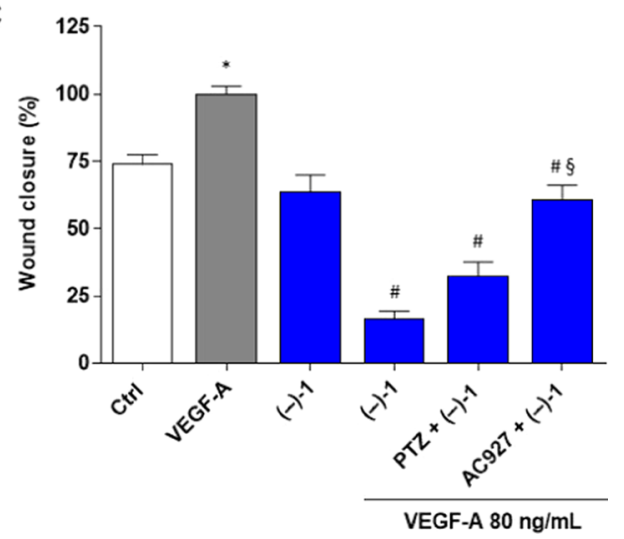

Figure 3. Evaluation of cell motility by wound healing assays in HREC treated with $80 \mathrm{ng} / \mathrm{mL}$ VEGF-A in the presence or absence of $5 \mu \mathrm{M}( \pm)-1(\mathrm{~A}),(+)-1(\mathrm{~B})$, and (-)-1 (C) at $48 \mathrm{~h}$. Selective $\sigma_{1}$ receptor agonist PTZ $(2 \mu \mathrm{M})$ or $\sigma_{2}$ receptor antagonist AC927 (2 $\mu \mathrm{M})$ was tested in cotreated HREC with $80 \mathrm{ng} / \mathrm{mL}$ of VEGF-A and $( \pm)-1,(+)-1$, or $(-)-1$. Wound closure percentage was quantified by ImageJ software. Ctrl, vehicle control (DMSO). Values are expressed as a mean \pm standard error of the mean (SEM) of three independent experiments, each involving three different wells per condition. Statistical analysis was performed using one-way analysis of variance (ANOVA), followed by Tukey's test. ${ }^{*} p<0.05$ vs Ctrl; ${ }^{\#} p<0.05$ vs VEGF-A; ${ }^{\S_{p}}<0.05$ vs the same conditions without agonist or antagonist.

model in vitro. On the one hand, all three dual-ligand prodrugs induce HREC cytotoxicity and inhibit VEGF-A-mediated HREC proliferation with greater potency than precursor compounds, mostly by inducing molecular mechanisms independent of $\sigma$ receptor signaling (Table 3 and Figure 2). In contrast, $( \pm)-\mathbf{1},(+)-\mathbf{1}$, and (-)-1 inhibit VEGF-A-

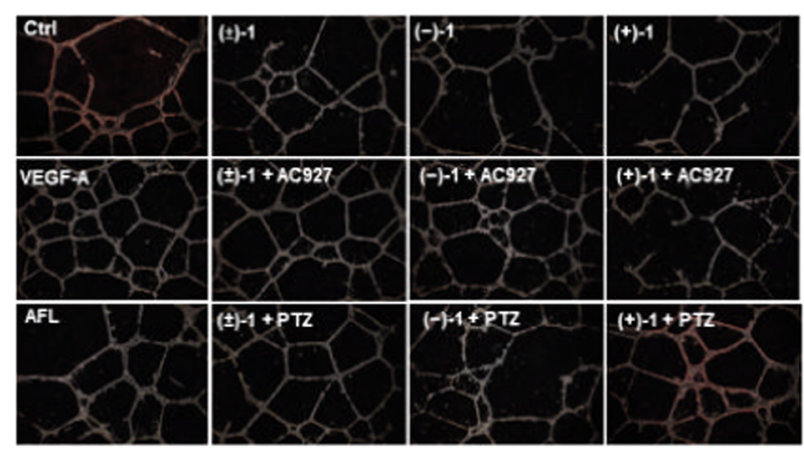

B

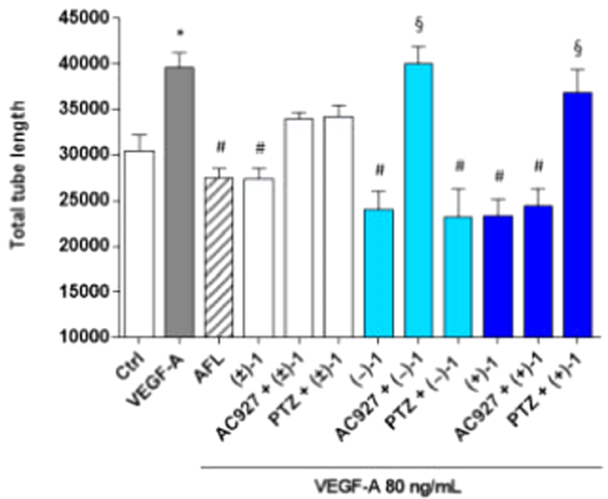

Figure 4. Effects $( \pm)-1,(+)-1$, and $(-)-1$ on tubelike structures formed by HREC stimulated with VEGF-A. Representative optical phase-contrast micrographs of tubelike structures (40X magnification) observed in the tube formation assays (Matrigel) at $24 \mathrm{~h}$ (A). Quantification of tube length was carried out using the Angiogenesis Analyzer tool for ImageJ software. HREC were treated with $80 \mathrm{ng} / \mathrm{mL}$ VEGF-A in the presence or absence of $5 \mu \mathrm{M}( \pm)-1,(+)-1$, and (-)-1 or further supplemented with selective $\sigma_{1}$ receptor agonist PTZ (2 $\mu \mathrm{M})$ and $\sigma_{2}$ receptor antagonist AC927 $(2 \mu \mathrm{M})$. We included HREC treated with $40 \mu \mathrm{g} / \mathrm{mL}$ of AFL (B). Values are expressed as mean \pm SEM of three independent experiments, each conducted in triplicate. Statistical analysis was performed using one-way ANOVA, followed by Tukey's test. ${ }^{*} p<0.05$ vs Ctrl; ${ }^{*} p<0.05$ vs VEGF-A; ${ }^{\circledR} p<0.05$ vs the same condition without agonist or antagonist.

stimulated HREC motility and tubelike structure formation stimulated by VEGF-A through the regulation of $\sigma$ receptor pathways (Figures 3 and 4). In particular, the actions of enantiomers (+)-1 and (-)-1 appear to be selectively mediated by $\sigma_{1}$ and $\sigma_{2}$ receptor signaling, respectively (Figures 3 and 4 ). Accordingly, the enantiomer mixture $( \pm)-1$ affects VEGF-Amediated HREC migration and tube formation by regulating simultaneously both $\sigma_{1}$ and $\sigma_{2}$ receptors (Figures 3 and 4 ). Our data highlighted a similar aptitude of $( \pm)-1$ and $(+)-1$ in counteracting the VEGF-A proangiogenic effect through a $\sigma_{1}$ receptor antagonist profile, as indicated by the PTZ capability to mitigate or completely block their effects. However, the (-)-1 enantiomer displays the strongest antiangiogenic activity, probably as a consequence of the superior binding activity as a $\sigma_{2}$ receptor agonist compared to the other dualligand prodrugs (Table 2 ). The superior inhibitory ability of (-)-1 against VEGF-A-stimulated HREC motility is of great significance, given the established role of cell migration and invasion in metastatic UM progression. ${ }^{42}$

Antiproliferative Activity on Human Uveal Melanoma 92-1 Cells. To evaluate signaling directly on UM cancer cells, the pharmacological effects of $( \pm)-1,(+)-1$, and $(-)-1$ were examined in human UM 92-1 cells. First, the presence of 
prodrug target molecules in the 92-1 tumor cell line was checked. HDACs are ubiquitous proteins expressed in all cell types, including UM 92-1 cells. ${ }^{43}$ Gene expressions of $\sigma_{1}$ and $\sigma_{2}$ receptors, in turn, were confirmed by reverse transcription polymerase chain reaction (RT-PCR). Similar to MCF-7 human breast cancer cells (used as positive controls), UM 92-1 cells possess transcripts for both the SIGMAR1 gene $\left(\sigma_{1}\right.$ receptor) and the TMEM97 gene ( $\sigma_{2}$ receptor), a novel finding in the field (Figure 5).

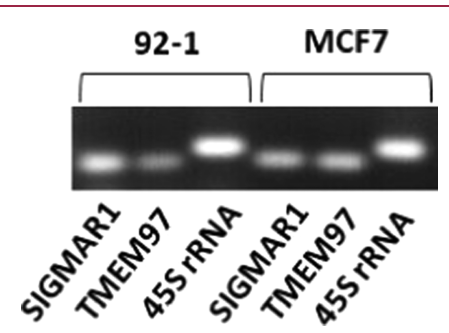

Figure 5. RT-PCR for the $\sigma_{1}$ (SIGMAR1) and $\sigma_{2}$ (TMEM97) receptor expression in UM 92-1 cells and MCF-7 human breast cancer cells. 45S Ribosomal pre-RNA was used as the positive control.

Then, actions on cell proliferation were examined by crystal violet staining (Figure 6). VPA, ( \pm )-HP-mII, and HP, as the precursor and component compounds of $( \pm)-1$, were employed at the predicted $\mathrm{IC}_{50}$ values and significantly inhibited 92-1 cell proliferation compared to the vehicle control (Figure 6A). ${ }^{32,44}$ However, by comparing precursor data with estimated $\mathrm{IC}_{50}$ values of prodrugs $[5.46 \mu \mathrm{M}$ for ( \pm )-1, $4.95 \mu \mathrm{M}$ for $(+)-1$, and $4.45 \mu \mathrm{M}$ for $(-)-1$, Table 4$]$, it is evident that the three prodrugs exhibited superior antiproliferative effects. Interestingly, no significant differences in efficacy or potency were observed among the three $( \pm)-1$ derivatives. Furthermore, application of the $\sigma_{1}$ agonist PTZ, $\sigma_{2}$ receptor antagonist $\mathrm{AC} 927$, or their combination did not perturb the antiproliferative effects of $( \pm)-1$ (Figure 6B), indicating that $\sigma$ receptors are not the main antiproliferative targets for $( \pm)-1$ in human UM 92-1 cells.

In fact, PTZ and AC927 alone promote, as expected, the proliferation of human UM 92-1 cells, while they are not able
Table 4. $\mathrm{IC}_{50}$ of $( \pm)-1,(+)-1$, and (-)-1 on Human 92-1 Cells at $48 \mathrm{~h}$

$\begin{array}{cc}\text { cmpd } & \mathrm{IC}_{50}(\mu \mathrm{M})^{a} \pm \mathrm{SD}^{b} \\ ( \pm)-1 & 5.5 \pm 0.74 \\ (+)-1 & 4.9 \pm 0.58 \\ (-)-1 & 4.4 \pm 0.68\end{array}$

${ }^{a} \mathrm{IC}_{50}$ values represent absolute estimates calculated with GraphPad Prism 5 for Windows using a nonlinear fit transform sigmoidal doseresponse (variable slope). $\mathrm{IC}_{50}$ values are averaged from multiple determinations $(n=3) .{ }^{b}$ Values are expressed as mean $\pm \mathrm{SD}$ of four independent experiments, each conducted in triplicate.

to restore the loss of cell viability induced by $( \pm)$-1 (Figure $6 \mathrm{~B})$. These results are in agreement with antiproliferative effects in HREC (Table 3 and Figure 2) and suggest that the inhibition of proliferation by prodrugs $( \pm)-1,(+)-\mathbf{1}$, and $(-)-1$ may reflect the HDACi activity by the VPA molecular component but not the $\sigma$ receptor signaling by the HPmII. ${ }^{29,30}$ Indeed, the almost identical antiproliferative potencies exhibited by the three prodrugs would be consistent with the invariable chemistry of VPA constituents but not with the diverse stereochemistry of HP-mII enantiomers, which substantially influences their different binding affinities for $\sigma$ receptors (Table 2). While excluding $\sigma$ receptor involvement in the regulation of proliferation by the three prodrug derivatives, present results do not rule out the possible offtarget contributions to VPA-dependent inhibition of proliferation, nor elucidate the exact molecular configuration of VPA interaction with the target (as a prodrug or separate, released metabolite).

Regardless, in UM 92-1 cells, superior antiproliferative effects (about 400 -fold) by the racemic mixture $( \pm)-1$ and enantiomers with respect to VPA alone (Figure 6A) point toward improved pharmacology provided by the dual-target/ dual-function strategy on VPA signaling through HDAC, presumably reflecting a VPA delivery to target sites facilitated by the prodrugs. ${ }^{45}$

Finally, tumor cell migration was explored with the wound healing assay (Figure 7). ( \pm )-1, (+)-1, and (-)-1 inhibited 921 cell migration over $48 \mathrm{~h}$ time courses (Figure 7A).
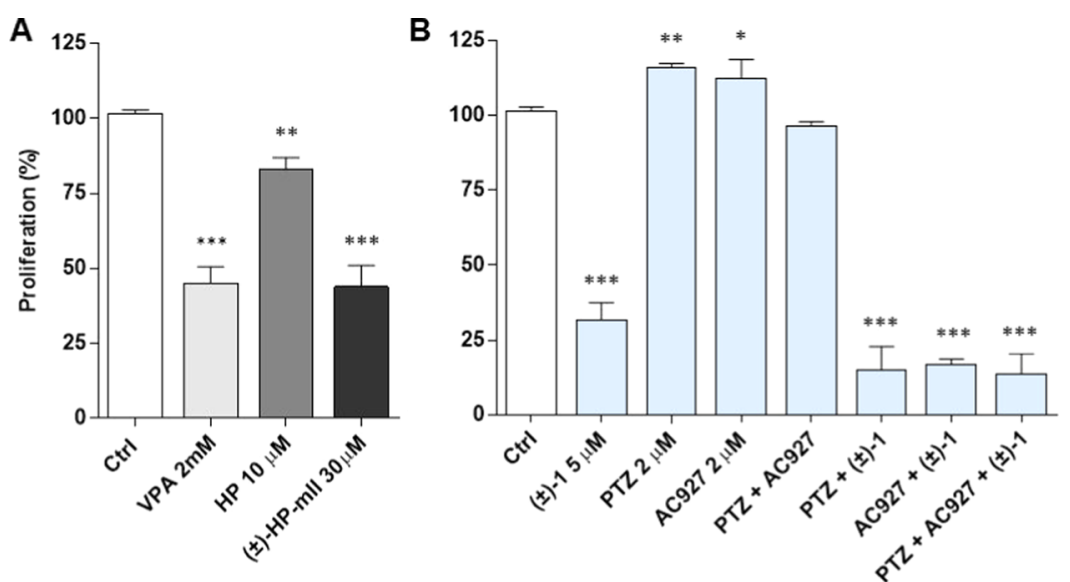

Figure 6. Effects of VPA $(2 \mathrm{mM})$, HP $(10 \mu \mathrm{M})$, and $( \pm)$-HP-mII $(30 \mu \mathrm{M})$ on $92-1$ cell proliferation (A). Antiproliferative effects of $( \pm)-1(5 \mu \mathrm{M})$ in combination with the selective $\sigma_{1}$ receptor agonist PTZ $(2 \mu \mathrm{M})$ and $\sigma_{2}$ receptor antagonist AC927 $(2 \mu \mathrm{M})$. Ctrl, vehicle control DMSO (B). Data in A and B represent the percentage of proliferation with respect to the vehicle control. Values are expressed as mean \pm SEM of four independent experiments, each conducted in triplicate. Statistical analysis was performed using one-way ANOVA, followed by Tukey's test. * $p<$ $0.05 ; * * p<0.01 ; * * p<0.001$ vs vehicle control. 

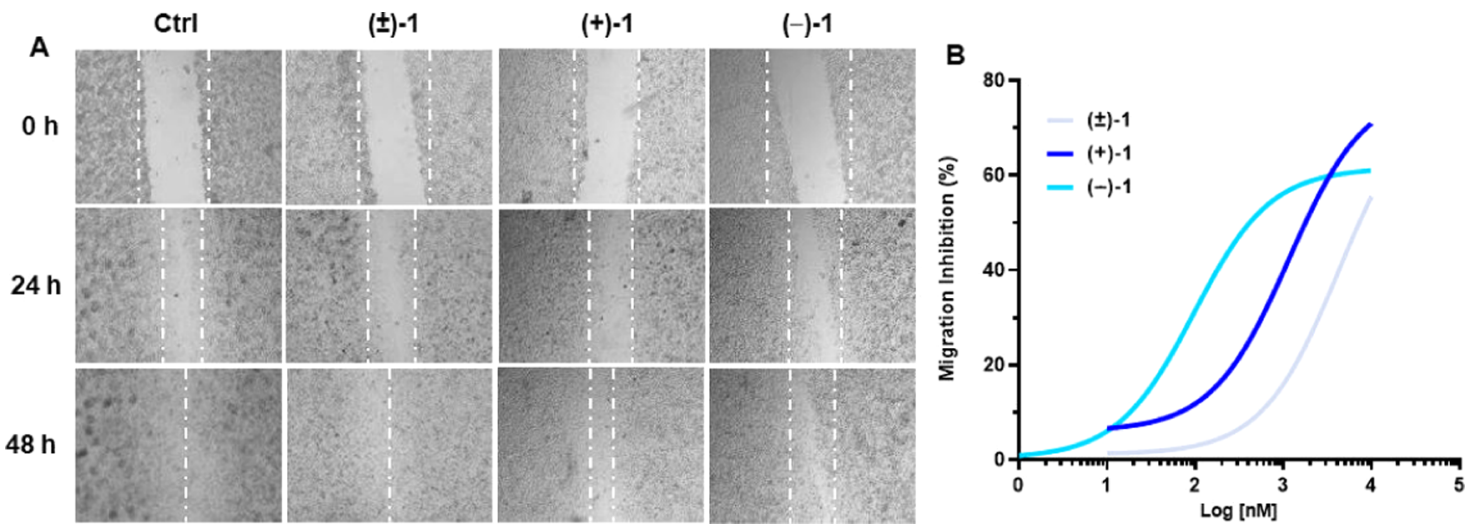

Figure 7. Effect of $( \pm)-1,(+)-1$, and (-)-1 on human 92-1 uveal melanoma cell migration. Representative images of the wound healing assay (A). Magnification, $4 \times$. All compounds were used at $3 \mu \mathrm{M}$. Ctrl, vehicle control (DMSO). Concentration-response curves of the inhibition of cell migration by the indicated compounds at the $48 \mathrm{~h}$ time point (B). Data are shown as \% inhibition of cell migration with respect to the vehicle control.

Remarkably, sigmoid dose-response curves (calculated at 48 h) demonstrated significantly different antimigratory potencies by the three prodrugs (Figure $7 \mathrm{~B}$ ) displaying $\mathrm{IC}_{50}$ values of $4.22 \mu \mathrm{M}$ for $( \pm)-1,1.15 \mu \mathrm{M}$ for $(+)-1$, and $0.09 \mu \mathrm{M}$ for $(-)-1$. In particular, the derivative (-)-1 exerted the highest antimigratory effects compared to the $(+)$-enantiomer $(>10$ fold) or the racemic mixture $( \pm)-1$ ( $>40$-fold; Figure $7 \mathrm{~B}$ ). These actions closely mirror those observed in HREC migration (Figure 3) and could similarly reflect signaling through $\sigma$ receptors by the HP-mII molecular component of the prodrugs, without VPA/HDAC involvement. Indeed, their differential potencies in motility inhibition (Figure 7) are aligned with increasing binding affinities for $\sigma_{2}$ receptors from $( \pm)-1$ to $(+)-1$ and (-)-1 (Table 2), thus implicating the stereochemical diversity of HP-mII enantiomeric components as an underlying molecular mechanism able to regulate cell migration. This hypothesis may also suggest that $( \pm)-\mathbf{1},(+)-\mathbf{1}$, and (-)-1 act predominantly as intact molecular moieties to inhibit cell motility, given the lack of symmetry between observed biological effects (antimigratory activity; Figure 7B) and receptor binding affinities by $( \pm)-\mathrm{HP}-\mathrm{mII}$ and single enantiomers (Table 2), which would be released upon prodrug metabolism.

Highest potency (Figure $7 \mathrm{~B}$ ) and $\sigma_{2}$ selectivity (Figure 3 ) by the enantiomer $(-)-1$, in turn, would be consistent with its significantly higher binding affinity for $\sigma_{2}$ receptors than the other two chemical analogues (Table 2) and a presumable biological dominance of $\sigma_{2}$ over $\sigma_{1}$ receptors in the context of cell migration. This latter consideration could explain the reciprocal contribution of both $\sigma_{1}$ and $\sigma_{2}$ receptors to inhibitory effects on HREC motility by $( \pm)-1$ and $(+)-1$ (Figure 3), with weaker $\sigma_{2}$ binding ligands than $(-$ )-1 (Table 2 ). Together, present observations in human 92-1 cells support the dual-target/dual-function strategy (HDACi and $\sigma$ ligands) underlying the asymmetric synthesis of both enantiomers. Thus, (+)-1 and (-)-1 provided potential UM therapeutics with superior, HDAC-mediated antiproliferative activities than single chemical precursors, and enhanced, $\sigma$ receptor-dependent antimigratory effects compared to the racemic $( \pm)-1$ mixture.

\section{CONCLUSIONS}

In this report, the synthesis and pharmacological characterization of the two enantiomers of ( \pm )-HP-mII valproate ester,
$( \pm)-1$, is presented. The results indicate that the three prodrugs exhibit antiangiogenic activity in vitro, comparable to the VEGF-trap AFL but with distinct pharmacological profiles. Indeed, while all compounds induce $\sigma$ receptor-independent HREC cytotoxicity to a similar extent, HREC migration and tube formation stimulated by VEGF-A are inhibited differently by the three prodrugs through the activation of selective $\sigma$ receptor signaling. In this context, the enantiomer (-)-1 displays the highest antimigratory effect on VEGF-Astimulated HREC by acting as a $\sigma_{2}$ receptor agonist. Investigations in human UM 92-1 cells demonstrated the potential of the dual-ligand prodrugs as novel anti-UM agents and confirmed molecular pharmacology findings obtained in HREC. In particular, ( \pm$)-1$ and its enantiomers induce pharmacologically equivalent cytotoxic effects on 92-1 cells, which are significantly greater than precursor compounds, probably dependent on the HDACi activity by the VPA molecular component but not related to $\sigma$ receptor signaling. In close agreement with the findings in HREC, all compound prodrugs also significantly inhibit UM 92-1 cell motility with different potencies. Again, the (-)-1 enantiomer displays the highest antimigratory activity on 92-1 cells, followed by the $(+)-1$ stereoisomer and the racemic mixture, pointing toward a presumable involvement of $\sigma$ receptor pathways and a biological dominance of $\sigma_{2}$ over $\sigma_{1}$ signaling in antimigratory effects by the dual-target/dual-function prodrugs. However, the exact molecular mechanisms underlying anti-UM effects by $(-)-1$ and its related prodrugs remain unclear and will be the focus of future studies.

On the basis of present findings, (-)-1 might represent a promising candidate for the development of pharmacological strategies to treat UM patients. In this context, beyond prodrugs with esterification, multiligand drug designs with simultaneous regulation of multiple targets could represent an alternative synthetic approach currently explored in this laboratory.

\section{EXPERIMENTAL SECTION}

Chemistry. Reagent grade chemicals were purchased from Merck KGaA (Darmstadt, Germany) and TCI Europe-Tokyo chemical industry (Tokyo, Japan) and were used without further purification. All reactions involving air-sensitive reagents were performed under $\mathrm{N}_{2}$ in oven-dried glassware using the syringe-septum cap technique. The reactions were monitored by thin-layer chromatography (TLC) 
performed on silica gel Merck $60 \mathrm{~F}_{254}$-coated aluminum plates; the spots were visualized by UV light $(\lambda=254 \mathrm{~nm})$ or iodine chamber. Melting points were determined on a Büchi B-450 apparatus in glass capillary tubes and are uncorrected. Optical rotations were taken at 20 ${ }^{\circ} \mathrm{C}$ with a PerkinElmer 241 polarimeter (Llantrisant, U.K.). Flash chromatography purification was performed on a Merck silica gel 60 (40-63 $\mu \mathrm{m} ; 230-400$ mesh) stationary phase. Nuclear magnetic resonance spectra $\left({ }^{1} \mathrm{H}\right.$ NMR and ${ }^{13} \mathrm{C}$ NMR recorded at $\left.500 \mathrm{MHz}\right)$ were obtained on Varian INOVA spectrometers using $\mathrm{CDCl}_{3}, \mathrm{D}_{2} \mathrm{O}$, and DMSO- $d_{6}$ with $0.03 \%$ tetramethylsilane (TMS) as the internal standard. Chemical shifts $(\delta)$ are given in parts per million (ppm) and coupling constants $(J)$ in Hertz $(\mathrm{Hz})$. Signal multiplicities are characterized as $\mathrm{s}=$ singlet, $\mathrm{d}=$ doublet, $\mathrm{t}=$ triplet, $\mathrm{q}=$ quartet, $\mathrm{m}=$ multiplet, and $\mathrm{br}=$ broad. High-resolution mass spectrometry (HRMS) was performed using an Orbitrap Fusion Tribrid mass spectrometer (Thermo Scientific). Compounds at the concentration of $10 \mu \mathrm{g} / \mathrm{mL}$ were dissolved in $\mathrm{ACN} / \mathrm{H}_{2} \mathrm{O}(80 / 20)+0.1 \%$ formic acid. Parameters: polarity (positive). Full scan mass was analyzed at a resolution of 120000 . Purities of all compounds reached at least $95 \%$ as determined by microanalysis $(\mathrm{C}, \mathrm{H}, \mathrm{N})$ that was performed on a Carlo Erba instrument model E1110; all of the results agreed within $\pm 0.4 \%$ of the theoretical values. Compound nomenclatures were generated with ChemBioDraw Ultra version 16.0.0.82.

Synthesis of Compounds (+)-3, (-)-3, (+)-4, and (-)-4. All compounds were synthesized as reported in the literature. ${ }^{33}$ General procedure and analytical and spectral data are reported in the Supporting Information.

General Procedure for the Synthesis of Compounds (+)-1 and (-)-1. To a solution of $(+)-4$ or $(-)-4(0.5 \mathrm{mmol})$ and triethylamine (TEA) $(1 \mathrm{mmol})$ in anhydrous THF $(6 \mathrm{~mL})$ was added 2-propylpentanoyl chloride $(2 \mathrm{mmol})$ at $0{ }^{\circ} \mathrm{C}$ and under stirring. The reaction was left at room temperature for $24 \mathrm{~h}$ under $\mathrm{N}_{2}$. The reaction mixture was quenched with $15 \mathrm{~mL}$ of water and stirred for $30 \mathrm{~min}$. To the mixture was added $\mathrm{CH}_{2} \mathrm{Cl}_{2}$, and the organic phase separated and washed with a solution of $4 \% \mathrm{NaHCO}_{3}(3 \times 25 \mathrm{~mL})$. The organic layers were dried over anhydrous $\mathrm{Na}_{2} \mathrm{SO}_{4}$, filtered, and evaporated. The crude was purified by flash chromatography $(1: 9 \mathrm{MeOH} /$ $\mathrm{CH}_{2} \mathrm{Cl}_{2}$ ) to obtain the final products $(+)-\mathbf{1}$ and $(-)-\mathbf{1}$ as colorless oil. Both enantiomers were transformed into oxalate salts.

(R)-(+)-4-[(4-Chlorophenyl)-4-hydroxypiperidin-1-yl]-1-(4fluorophenyl)butyl-2-propylpentanoate $[(R)-(+)-M R J F 22$ Oxalate, $(+)-1]$. According to the general procedure, compound (+)-1 was prepared by reacting 2-propylpentanoyl chloride $(0.195 \mathrm{~g}, 1.2 \mathrm{mmol})$ and compound (+)-4 (0.113 g, $0.3 \mathrm{mmol})$. Yield: $0.095 \mathrm{~g}(63 \%)$, white solid. Mp: $159-164{ }^{\circ} \mathrm{C}$. $[\alpha]_{\mathrm{D}}^{20}=+24.8^{\circ}\left(c 1.0, \mathrm{CHCl}_{3}\right) .92 \%$ ee ${ }^{1} \mathrm{H}$ NMR (500 MHz, DMSO- $\left.d_{6}\right): \delta 7.51-7.45(\mathrm{~m}, 2 \mathrm{H}), 7.44-7.38$ $(\mathrm{m}, 4 \mathrm{H}), 7.20(\mathrm{t}, J=10.0 \mathrm{~Hz}, 2 \mathrm{H}), 5.72(\mathrm{t}, J=5.0 \mathrm{~Hz}, 1 \mathrm{H}), 3.33-$ $3.19(\mathrm{~m}, 2 \mathrm{H}), 3.18-2.99(\mathrm{~m}, 4 \mathrm{H}), 2.37(\mathrm{~m}, 1 \mathrm{H}), 2.22-2.07(\mathrm{~m}, 2 \mathrm{H})$, $1.91-1.85(\mathrm{~m}, 1 \mathrm{H}), 1.81-1.53(\mathrm{~m}, 5 \mathrm{H}), 1.52-1.43(\mathrm{~m}, 2 \mathrm{H}), 1.42-$ $1.43(\mathrm{~m}, 2 \mathrm{H}), 1.23-1.09(\mathrm{~m}, 4 \mathrm{H}), 0.84(\mathrm{t}, J=5.0 \mathrm{~Hz}, 3 \mathrm{H}), 0.79(\mathrm{t}, J$ $=5.0 \mathrm{~Hz}, 3 \mathrm{H}) \cdot{ }^{13} \mathrm{C}$ NMR $\left(125 \mathrm{MHz}, \mathrm{DMSO}-d_{6}\right): \delta 174.6,164.6\left(J_{\mathrm{CF}}\right.$ $=213.75 \mathrm{~Hz}), 146.9,136.5,131.4,128.5,128.4\left(J_{\mathrm{CF}}=7.5 \mathrm{~Hz}\right), 126.6$, $115.2\left(J_{\mathrm{CF}}=21.25 \mathrm{~Hz}\right), 73.8,67.9,47.9,48.9,44.4,37.9,35.04,34.03$, 33.9, 20.04, 19.9, 19.8, 13.7. HR-MS: $m / z[\mathrm{M}+\mathrm{H}]^{+}$calcd for $\mathrm{C}_{29} \mathrm{H}_{40} \mathrm{ClFNO}_{3}:$ 504.2681, found: 504.2663. Anal. calcd for $\mathrm{C}_{31} \mathrm{H}_{41} \mathrm{ClFNO}_{7}$ : C, 74.17; H, 8.58; N, 2.98. Found: C, 74.22; H, $8.61 ; \mathrm{N}, 2.98$.

(S)-(-)-4-[(4-Chlorophenyl)-4-hydroxypiperidin-1-yl]-1-(4fluorophenyl)butyl-2-propylpentanoate [(S)-(-)-MRJF22 Oxalate, $(-)-1]$. According to the general procedure, compound (-)-1 was prepared by reacting 2-propylpentanoyl chloride $(0.325 \mathrm{~g}, 2.0 \mathrm{mmol})$ and compound (-) $-4(0.189 \mathrm{~g}, 0.5 \mathrm{mmol})$. Yield: $0.252 \mathrm{~g}(100 \%)$, white solid. Mp: $158-160^{\circ} \mathrm{C}$. $[\alpha]_{D}^{20}=-26.0^{\circ}\left(c 1.0, \mathrm{CHCl}_{3}\right) \cdot 95.4 \%$ ee ${ }^{1} \mathrm{H}$ NMR (500 MHz, DMSO-d 6 ): $\delta$ 7.50-7.46 (m, 2H), 7.44-7.38 $(\mathrm{m}, 4 \mathrm{H}), 7.20(\mathrm{t}, J=10.0 \mathrm{~Hz}, 2 \mathrm{H}), 5.72(\mathrm{t}, J=5.0 \mathrm{~Hz}, 1 \mathrm{H}), 3.33-$ $3.19(\mathrm{~m}, 2 \mathrm{H}), 3.18-2.99(\mathrm{~m}, 4 \mathrm{H}), 2.37(\mathrm{~m}, 1 \mathrm{H}), 2.22-2.07(\mathrm{~m}, 2 \mathrm{H})$, $1.91-1.85(\mathrm{~m}, 1 \mathrm{H}), 1.81-1.53(\mathrm{~m}, 5 \mathrm{H}), 1.52-1.43(\mathrm{~m}, 2 \mathrm{H}), 1.42-$ $1.43(\mathrm{~m}, 2 \mathrm{H}), 1.23-1.09(\mathrm{~m}, 4 \mathrm{H}), 0.84(\mathrm{t}, J=5.0 \mathrm{~Hz}, 3 \mathrm{H}), 0.79(\mathrm{t}, J$ $=5.0 \mathrm{~Hz}, 3 \mathrm{H}) \cdot{ }^{13} \mathrm{C}$ NMR $\left(125 \mathrm{MHz}, \mathrm{DMSO}-d_{6}\right): \delta 174.4,162.4\left(J_{\mathrm{CF}}\right.$ $=212.5 \mathrm{~Hz}), 146.7,136.4,131.3,128.3\left(J_{\mathrm{CF}}=8.7 \mathrm{~Hz}\right), 120.9,127.9$,
$126.5,115.0\left(J_{\mathrm{CF}}=21.25 \mathrm{~Hz}\right), 73.6,67.7,44.3,33.9,33.8,32.6,19.9$, 19.8, 19.7, 13.6, 13.5. HR-MS: $m / z[\mathrm{M}+\mathrm{H}]^{+}$calcd for $\mathrm{C}_{29} \mathrm{H}_{40} \mathrm{ClFNO}_{3}:$ 504.2681, found: 504.2663. Anal. calcd for $\mathrm{C}_{31} \mathrm{H}_{41} \mathrm{ClFNO}_{7}$ : C, 74.17; H, 8.58; N, 2.98. Found: C, 74.22; H, $8.61 ; \mathrm{N}, 2.98$

Chromatographic Conditions. The liquid chromatography system was an Agilent 1260 Infinity II HPLC (Agilent, Santa Clara, CA) consisting of a 1260 Infinity II Quaternary Pump (model G7111A), 1260 Infinity II autosampler (model G7129A), a 1260 Infinity II Multicolumn Thermostat (model G7116A), and a 1260 Infinity II Diode Array Detector (model G7115A). Data were acquired and integrated using the software Agilent OpenLab CDS LC ChemStation. The separation was performed using a Poroshell 120 EC-C18 $(150 \times 4.6 \mathrm{~mm}$ i.d., particle size $4 \mu \mathrm{m}$; Agilent, Santa Clara $)$, maintained at $20^{\circ} \mathrm{C}$. The samples were run using a mixture of water (A) and acetonitrile (B) enriched with trifluoroacetic acid (0.1\% v/v). The gradient used was from $80 \%$ A to $100 \%$ B over $10 \mathrm{~min}$. The flow rate was $0.8 \mathrm{~mL} / \mathrm{min}$. The UV detector was set at a length of $254 \mathrm{~nm}$. Enantioselective HPLC analyses were performed using the same above-described conditions except for the stationary phase, which was a Chiralcel OJ[-RH] column $(150 \times 4.6 \mathrm{~mm}, 5 \mu \mathrm{m})$.

Kinetics of Chemical Hydrolysis. A $0.02 \mathrm{M}$ phosphate buffer (PBS, pH 7.4) and a $0.02 \mathrm{M}$ hydrochloric buffer ( $\mathrm{pH} 1.3$ ) containing $0.1 \%(\mathrm{v} / \mathrm{v})$ Cremophor ELP, was used to evaluate chemical stabilities at physiological $\mathrm{pHs}$. The reaction was initiated by adding $1 \mathrm{~mL}$ of $10^{-4} \mathrm{M}$ stock solution (in acetonitrile) of the compound to $10 \mathrm{~mL}$ of thermostated $\left(37 \pm 0.5{ }^{\circ} \mathrm{C}\right)$ buffer solution. At established time points, the samples $(20 \mu \mathrm{L})$ were withdrawn and analyzed by HPLC. Pseudo-first-order rate constants $\left(k_{\text {obs }}\right)$ for the hydrolysis of the compounds were then calculated considering the slopes of the linear plots of $\log$ (\% residual compound) against time. The analyses were run in triplicate, and the mean values of the rate constants were calculated.

Kinetics of Enzymatic Hydrolysis. Human plasma was purchased from $3 \mathrm{H}$ Biomedical (Uppsala, Sweden, Europe). Plasma aliquots $(4 \mathrm{~mL})$ were diluted with $0.02 \mathrm{M}$ PBS ( $\mathrm{pH} 7.4)$ to obtain a final volume of $5 \mathrm{~mL}$ containing $80 \%$ plasma. Studies were performed at $37 \pm 0.5{ }^{\circ} \mathrm{C}$ using a shaking bath. Each experiment was started by adding a $10^{-4} \mathrm{M}$ drug stock solution $(200 \mu \mathrm{L})$ to the preheated plasma. Hundred microliters of the thermostated medium was taken at various times, treated with cold methanol $(500 \mu \mathrm{L})$ to precipitate plasma proteins, and centrifugated ( $5 \mathrm{~min}$ at $5000 \mathrm{~g})$. The supernatant was analyzed by HPLC to quantify the amount of the residual intact compound.

Receptor Binding Studies. The $\sigma_{1}$ and $\sigma_{2}$ receptor binding studies were performed according to the literature. ${ }^{46,47}$ Briefly, for the $\sigma_{1}$ receptor binding assay, guinea pig brain membranes $(400 \mu \mathrm{L}, 500$ $\mu \mathrm{g}$ protein) were incubated for $150 \mathrm{~min}$ at $37^{\circ} \mathrm{C}$ with $3 \mathrm{nM}$ of the radiolabeled ligand $\left[{ }^{3} \mathrm{H}\right]-(+)$-pentazocine $(45 \mathrm{Ci} / \mathrm{mmol})$ and increasing concentrations of tested compounds in $50 \mathrm{mM}$ Tris- $\mathrm{HCl}$ ( $\mathrm{pH}$ 7.4) to a total volume of $1 \mathrm{~mL}$. Nonspecific binding was assessed in the presence of $10 \mu \mathrm{M}$ unlabeled haloperidol. Moreover, $\sigma_{2}$ receptor binding assays were made according to the following protocol: the guinea pig brain membranes $(300 \mu \mathrm{L}, 360 \mu \mathrm{g}$ protein) were incubated for $120 \mathrm{~min}$ at room temperature with $3 \mathrm{nM}\left[{ }^{3} \mathrm{H}\right]$ DTG $(31 \mathrm{Ci} / \mathrm{mmol})$ in the presence of $0.4 \mathrm{mM}$ radiolabeled ligand (+)-SKF10,047 to block the $\sigma_{1}$ sites. The incubation was performed in $50 \mathrm{mM}$ Tris- $\mathrm{HCl}(\mathrm{pH} 8.0)$ to a total volume of $0.5 \mathrm{~mL}$ with increasing concentrations of each test compound. Nonspecific binding was evaluated in the presence of $5 \mu \mathrm{M}$ DTG.

Each sample was filtered through Whatman GF/B glass fiber filters, which were presoaked for $1 \mathrm{~h}$ in a $0.5 \%$ poly(ethylenimine) solution, using a Millipore filter apparatus. Filters were washed twice with $4 \mathrm{~mL}$ of ice-cold buffer. Radioactivity was counted in $4 \mathrm{~mL}$ of "Ultima Gold MV" in a 1414 WinSpectral PerkinElmer Wallac or Beckman LS6500 scintillation counter. Inhibition constants $\left(K_{\mathrm{i}}\right.$ values) were calculated using the EBDA/LIGAND program purchased from Elsevier/Biosoft.

Cell Cultures. Primary HREC were purchased from Innoprot (Elexalde Derio, Spain) and were fed with culture EC medium, supplemented with $5 \%$ fetal bovine serum (FBS), $1 \%$ endothelial cell 
growth supplement (ECGS), $100 \mathrm{U} / \mathrm{mL}$ penicillin, and $100 \mu \mathrm{g} / \mathrm{mL}$ streptomycin provided by Innoprot. The cells were plated in T25 culture flasks (Costar; Corning, New York, NY), precoated with fibronectin (Innoprot) for $1 \mathrm{~h}$ at $37{ }^{\circ} \mathrm{C}$. Further, human uveal melanoma (UM) 92-1 cell line was purchased from the Cell FactoryIST (Genoa, Italy). Human UM cell line 92-1 (passages 2-15) were maintained at $37{ }^{\circ} \mathrm{C}\left(5 \% \mathrm{CO}_{2}\right)$ in RPMI-1640 medium, containing $10 \%$ fetal bovine serum (FBS), $2 \mathrm{mM}$ L-glutamine, 100 units $/ \mathrm{mL}$ penicillin, and $100 \mu \mathrm{g} / \mathrm{mL}$ streptomycin. ${ }^{48}$ Breast cancer cell line MCF-7, obtained from the American Type Culture Collection (ATCC; Manassas, VA), was maintained at $37{ }^{\circ} \mathrm{C}\left(5 \% \mathrm{CO}_{2}\right)$ in Eagle's Minimum Essential Medium, containing 10\% FBS, 2 mM Lglutamine, 100 units $/ \mathrm{mL}$ penicillin, $100 \mu \mathrm{g} / \mathrm{mL}$ streptomycin, and $0.01 \mathrm{mg} / \mathrm{mL}$ human recombinant insulin. All cell media and reagents were from Euroclone S.p.A. (Pero, Milan, Italy). (+)-Pentazocine (Italian Minister of Health permit to produce and use SP/072 05/04/ 2019) and AC927 were prepared according to published methods. ${ }^{49,50}$

MTT Assay. For cell viability assays, the 3-[4,5-dimethylthiazol-2yl]-2,5-diphenyltetrazolium bromide (MTT assay, Chemicon, Temecula, CA) was used. The cells were seeded in 96-well plates at a density of $1.5 \times 10^{4}$ cells/well and were incubated overnight at $37^{\circ} \mathrm{C}$ before the experiment. Afterward, the cells were treated for 24,48 , and $72 \mathrm{~h}$ in the presence of different concentrations (1.0, 2.5, 5.0, $10.0,20.0 \mu \mathrm{M})$ of $( \pm)-1,(+)-1$, or $(-)-1$. After the treatments, the cells were incubated with MTT $(5 \mathrm{mg} / \mathrm{mL})$ for $3 \mathrm{~h}$, and then $100 \mu \mathrm{L}$ of dimethyl sulfoxide was added, and the absorbance was read in a plate reader (Synergy 2-BioTek) with a wavelength of $570 \mathrm{~nm}$.

Cell Proliferation. HREC and human 92-1 cell (seeded $4 \times 10^{3}$ and grown for $24 \mathrm{~h}$ at optimum culture conditions) proliferation was measured using crystal violet staining after treatment in 96-well plates with the indicated concentrations of chemicals for an additional $48 \mathrm{~h}$. Control cells received an equal volume of vehicle (DMSO). At the end of the treatment, each well was washed with phosphate-buffered saline (PBS). Following this, the cells were fixed (in 4\% paraformaldehyde) and stained with crystal violet solution $(0.5 \%$ in $20 \%$ methanol for HREC or $1 \%$ aqueous solution for 92-1 cells). Subsequently, the plate was washed with water and left to dry. Crystal violet staining was evaluated by measuring the absorbance at $570 \mathrm{~nm}$ or $590 \mathrm{~nm}$, after crystal violet extraction with $10 \%$ acetic acid (at room temperature for $10 \mathrm{~min}$ ), with a microplate reader with the plate reader (Synergy 2-BioTek). For quantification, each assay was carried out in triplicate.

Wound Healing Assay. HREC and 92-1 cells $\left(2.5 \times 10^{5}\right.$ cells/ well) were seeded into 24 well plates and grown to confluency. Confluent cell monolayers were scratched with a p200 pipet tip to create $1 \mathrm{~mm}$ wide wounds. After washing (three times) with PBS to remove cell debris, wounded monolayers were incubated for $48 \mathrm{~h}$ (37 ${ }^{\circ} \mathrm{C}$ ) in the complete medium in the presence of the indicated treatments. HREC were treated for $48 \mathrm{~h}$ in the presence of $( \pm)-1$, $(+)-1$, or $(-)-1$ with or without VEGF-A $(80 \mathrm{ng} / \mathrm{mL})$, AC927, and PTZ. 92-1 cells were treated for $48 \mathrm{~h}$ in the presence of $( \pm)-\mathbf{1},(+)-\mathbf{1}$, or (-)-1. Wound closure was monitored by photographs at $40 \mathrm{X}$ using a phase-contrast microscope in each culture condition and at each time point $(0,24$, and $48 \mathrm{~h}$ for HREC and $0,6,24,30$, and $48 \mathrm{~h}$ for 92-1 cells). The numbers of cells toward the wounds were counted using ImageJ software (ImageJ 1.50e, National Institutes of Health, $\mathrm{NIH}$, Bethesda, MD) and were quantified by measuring the distance traveled over time by both cell fronts into the wound area.

Tube Formation Assay. The tube formation assay was analyzed in vitro in $\mathrm{BD}$ Matrigel, following the manufacturer's instructions (BD, Bedford). In brief, 96-well plates were coated with $50 \mu \mathrm{L}$ of Matrigel and allowed to solidify at $37^{\circ} \mathrm{C}$ for $2 \mathrm{~h}$. HREC were seeded at $1.5 \times 10^{4}$ cells/well in $100 \mu \mathrm{L}$ of medium with $( \pm)-1,(+)-1$, or $(-)-1$ in the presence or absence of VEGF-A $(80 \mathrm{ng} / \mathrm{mL})$, AC927, and PTZ. After $8 \mathrm{~h}$ of incubation, tubelike structures were photographed at $10 \times$ magnification using an inverted microscope (Leica DM IRB) equipped with a CCD camera. Tube formations were quantified with ImageJ software (NIH, Bethesda, MD).
Total RNA and RT-PCR. Total RNA was extracted from cell cultures employing Direct-zol RNA Miniprep (Zymo Research, California) according to manufacturer's instructions and redissolved in $30 \mu \mathrm{L}$ of RNase-free water. RNA concentrations and purity were estimated by optical density at 260 and $280 \mathrm{~nm}$. The first-strand cDNA was reversely transcribed using the High-Capacity cDNA Reverse Transcription Kit (Applied Biosystems, California) in a $20 \mu \mathrm{L}$ reaction volume. Aliquots of cDNA were amplified using specific primers for the $\sigma_{1}$ receptor (SIGMAR1, F: 5'-GTGAGGTCTTCTACCCAG-3' and R: 5'-GAAGAGGGTGAGGAAGTC-3'), $\sigma_{2}$ receptor (TMEM97, F:5'-CCTGGTTTAAGTCCTTTCTG-3'; R:CTCAAACAGAAATGTGGAGAG- $3^{\prime}$ ), and the positive control 45S Ribosomal pre-RNA (F: CGCGCTCTACCTTACCTACCT and R:CGTCGGCATGTATTAGCTCT), producing three specific amplification products of $173 \mathrm{bp}, 173 \mathrm{bp}$, and $199 \mathrm{bp}$, respectively. PCR reactions were carried out employing the Wonder Taq kit (Euroclone). PCR parameters were as follows: initial denaturing, 95 ${ }^{\circ} \mathrm{C}$ for $3 \mathrm{~min}$; 35 cycles of denaturing at $95^{\circ} \mathrm{C}$ for $15 \mathrm{~s}$; annealing at $54{ }^{\circ} \mathrm{C}$ (SIGMAR1), $56{ }^{\circ} \mathrm{C}$ (TMEM97), or $59{ }^{\circ} \mathrm{C}$ (45S Ribosomal pre-RNA) for $15 \mathrm{~s}$ and extension at $72^{\circ} \mathrm{C}$ for $30 \mathrm{~s}$; and final extension step, $72{ }^{\circ} \mathrm{C}$ for $7 \mathrm{~min}$. Primers for RT-PCR were purchased from Sigma Aldrich (St. Louis, Missouri).

Statistical Analysis. All results are reported as mean \pm SEM from at least two or three independent experiments $(n=2$ or 3$)$ performed at least in duplicate or triplicate. The results were analyzed using oneway ANOVA followed by Tukey-Kramer multiple comparisons test; differences between groups were considered significant for $p$-value < 0.05 .

\section{ASSOCIATED CONTENT}

\section{Supporting Information}

The Supporting Information is available free of charge at https://pubs.acs.org/doi/10.1021/acs.jmedchem.1c00995.

Detailed procedures for the preparation of compounds (+)-3, (-)-3, (+)-4, and (-)-4; HPLC chromatograms of compounds $( \pm)-\mathbf{1},(+)-\mathbf{1}$, or $(-)-\mathbf{1}$; the MTT assay concentration-response curve on HREC; representative images of scratched cells treated with VEGF-A and the wound healing assay on HREC of compounds ( \pm )-1, (+)-1, or (-)-1; ${ }^{1} \mathrm{H}$ and ${ }^{13} \mathrm{C}$ NMR spectra and HRMS spectra (PDF)

Molecular formula strings (CSV)

\section{AUTHOR INFORMATION}

\section{Corresponding Authors}

Giovanni Mario Pitari - Vera Salus Ricerca S.r.l., 96100

Siracusa, Italy; ○ orcid.org/0000-0003-0698-8112; Phone: (+39) 0931 1987360; Email: giovanni.pitari@ verasalusricerca.it

Carmelina Daniela Anfuso - Department of Biomedical and Biotechnological Sciences, School of Medicine, University of Catania, 95123 Catania, Italy; Phone: (+39) 095 4781170; Email: daniela.anfuso@unict.it

Agostino Marrazzo - Department of Drug and Health Sciences, University of Catania, 95125 Catania, Italy; (1) orcid.org/0000-0002-8728-8857; Phone: (+39) 095 7834250; Email: marrazzo@unict.it

\section{Authors}

Carla Barbaraci - Department of Drug and Health Sciences, University of Catania, 95125 Catania, Italy; Vera Salus Ricerca S.r.l., 96100 Siracusa, Italy; 이이.org/00000002-6155-6702 
Giovanni Giurdanella - Department of Biomedical and Biotechnological Sciences, School of Medicine, University of Catania, 95123 Catania, Italy

Claudia Giovanna Leotta - Vera Salus Ricerca S.r.l., 96100 Siracusa, Italy

Anna Longo - Department of Biomedical and Biotechnological Sciences, School of Medicine, University of Catania, 95123 Catania, Italy

Emanuele Amata - Department of Drug and Health Sciences, University of Catania, 95125 Catania, Italy; (1) orcid.org/ 0000-0002-4750-3479

Maria Dichiara - Department of Drug and Health Sciences, University of Catania, 95125 Catania, Italy

Lorella Pasquinucci - Department of Drug and Health Sciences, University of Catania, 95125 Catania, Italy; ○ orcid.org/0000-0003-1309-3368

Rita Turnaturi - Department of Drug and Health Sciences, University of Catania, 95125 Catania, Italy; (- orcid.org/ 0000-0002-5895-7820

Orazio Prezzavento - Department of Drug and Health Sciences, University of Catania, 95125 Catania, Italy; (1) orcid.org/0000-0002-3521-264X

Ivana Cacciatore - Department of Pharmacy, "G. D'Annunzio" University of Chieti-Pescara, 66100 Chieti Scalo, Italy; 10 orcid.org/0000-0001-6253-0443

Elisa Zuccarello - Taub Institute for Research on Alzheimer's Disease and the Aging Brain, Columbia University, New York, New York 10032, United States

Gabriella Lupo - Department of Biomedical and Biotechnological Sciences, School of Medicine, University of Catania, 95123 Catania, Italy

Complete contact information is available at:

https://pubs.acs.org/10.1021/acs.jmedchem.1c00995

\section{Author Contributions}

${ }^{\#}$ C.B. and G.G. contributed equally to this work.

\section{Funding}

PON FSE-FESR R\&I funds 2014-2020 Action I. 1 (CUP: E77H18000450006, DOT1708221, grant 3). Italian MUR for supporting grant PRIN 2017 (Code 201744BN5T). Additional funding was provided by Vera Salus Ricerca S.r.l.

\section{Notes}

The authors declare the following competing financial interest(s): CGL is employee of Vera Salus Ricerca S.r.l. GMP is a co-founder, shareholder and the Chief Scientific Officer of Vera Salus Ricerca S.r.l.

\section{ABBREVIATIONS}

AFL, aflibercept; BRB, blood-retinal barrier; DIP-Cl, diisopinocampheylchloroborane; FBS, fetal bovine serum; HDACi, histone deacetylase inhibitor; hERG, human voltage-dependent $\mathrm{K}^{+}$channel; HP, haloperidol; HP-mII, haloperidol metabolite II; HREC, human retinal endothelial cell; (+)-PTZ, (+)-pentazocine; RT-PCR, reverse transcription polymerase chain reaction; TEA, triethylamine; TLC, thinlayer chromatography; UM, uveal melanoma; VEGF-A, vascular endothelial growth factor A; VPA, valproic acid

\section{REFERENCES}

(1) Kaliki, S.; Shields, C. L. Uveal melanoma: relatively rare but deadly cancer. Eye 2017, 31, 241-257.
(2) Andreoli, M. T.; Mieler, W. F.; Leiderman, Y. I. Epidemiological trends in uveal melanoma. Br. J. Ophthalmol. 2015, 99, 1550-1553.

(3) Virgili, G.; Gatta, G.; Ciccolallo, L.; Capocaccia, R.; Biggeri, A.; Crocetti, E.; Lutz, J. M.; Paci, E.; Group, E. W. Survival in patients with uveal melanoma in Europe. Arch. Ophthalmol. 2008, 126, 14131418.

(4) Kujala, E.; Mäkitie, T.; Kivelä, T. Very long-term prognosis of patients with malignant uveal melanoma. Invest. Ophthalmol. Visual Sci. 2003, 44, 4651-4659.

(5) Chattopadhyay, C.; Kim, D. W.; Gombos, D. S.; Oba, J.; Qin, Y.; Williams, M. D.; Esmaeli, B.; Grimm, E. A.; Wargo, J. A.; Woodman, S. E.; Patel, S. P. Uveal melanoma: from diagnosis to treatment and the science in between. Cancer 2016, 122, 2299-2312.

(6) Mäkitie, T.; Summanen, P.; Tarkkanen, A.; Kivelä, T. Microvascular loops and networks as prognostic indicators in choroidal and ciliary body melanomas. J. Natl. Cancer Inst. 1999, 91, 359-367.

(7) Campochiaro, P. A.; Clark, W. L.; Boyer, D. S.; Heier, J. S.; Brown, D. M.; Vitti, R.; Kazmi, H.; Berliner, A. J.; Erickson, K.; Chu, K. W.; Soo, Y.; Cheng, Y.; Haller, J. A. Intravitreal aflibercept for macular edema following branch retinal vein occlusion: the 24-week results of the vibrant study. Ophthalmology 2015, 122, 538-44.

(8) Brown, D. M.; Heier, J. S.; Clark, W. L.; Boyer, D. S.; Vitti, R.; Berliner, A. J.; Zeitz, O.; Sandbrink, R.; Zhu, X.; Haller, J. A. Intravitreal aflibercept injection for macular edema secondary to central retinal vein occlusion: 1-year results from the phase 3 copernicus study. Am. J. Ophthalmol. 2013, 155, 429-437.e7.

(9) Tarhini, A. A.; Frankel, P.; Margolin, K. A.; Christensen, S.; Ruel, C.; Shipe-Spotloe, J.; Gandara, D. R.; Chen, A.; Kirkwood, J. M. Aflibercept (VEGF Trap) in inoperable stage III or stage IV melanoma of cutaneous or uveal origin. Clin. Cancer Res. 2011, 17, $6574-6581$

(10) Treatment with Intravitreal Avastin for Large Uveal Melanomas, 2016. https://ClinicalTrials.gov/show/NCT00596362.

(11) Maj, E.; Papiernik, D.; Wietrzyk, J. Antiangiogenic cancer treatment: the great discovery and greater complexity (Review). Int. J. Oncol. 2016, 49, 1773-1784.

(12) Buder, K.; Gesierich, A.; Gelbrich, G.; Goebeler, M. Systemic treatment of metastatic uveal melanoma: review of literature and future perspectives. Cancer Med. 2013, 2, 674-686.

(13) Bowen, W. D. Sigma receptors: recent advances and new clinical potentials. Pharm. Acta Helv. 2000, 74, 211-218.

(14) Smith, S. B. Introduction to sigma receptors: their role in disease and as therapeutic targets. Adv. Exp. Med. Biol. 2017, 964, 14.

(15) Crottès, D.; Rapetti-Mauss, R.; Alcaraz-Perez, F.; Tichet, M.; Gariano, G.; Martial, S.; Guizouarn, H.; Pellissier, B.; Loubat, A.; Popa, A.; Paquet, A.; Presta, M.; Tartare-Deckert, S.; Cayuela, M. L.; Martin, P.; Borgese, F.; Soriani, O. SigmaR1 regulates membrane electrical activity in response to extracellular matrix stimulation to drive cancer cell invasiveness. Cancer Res. 2016, 76, 607-618.

(16) Alon, A.; Schmidt, H. R.; Wood, M. D.; Sahn, J. J.; Martin, S. F.; Kruse, A. C. Identification of the gene that codes for the sigma2 receptor. Proc. Natl. Acad. Sci. U.S.A. 2017, 114, 7160-7165.

(17) Yang, K.; Zeng, C.; Wang, C.; Sun, M.; Yin, D.; Sun, T. Sigma-2 receptor-a potential target for cancer/alzheimer's disease treatment via its regulation of cholesterol homeostasis. Molecules 2020, 25, No. 5439.

(18) Xie, X.-Y.; Li, Y.-Y.; Ma, W.-H.; Chen, A.-F.; Sun, Y.-T.; Lee, J. Y.; Riad, A.; Xu, D.-H.; Mach, R. H.; Huang, Y.-S. Synthesis, binding, and functional properties of tetrahydroisoquinolino-2-alkyl phenones as selective $\sigma 2 \mathrm{R} / \mathrm{TMEM} 97$ ligands. Eur. J. Med. Chem. 2021, 209, No. 112906.

(19) Jiang, G.; Mysona, B.; Dun, Y.; Gnana-Prakasam, J. P.; Pabla, N.; Li, W.; Dong, Z.; Ganapathy, V.; Smith, S. B. Expression, subcellular localization, and regulation of sigma receptor in retinal muller cells. Invest. Ophthalmol. Visual Sci. 2006, 47, 5576-5582.

(20) Longhitano, L.; Castracani, C. C.; Tibullo, D.; Avola, R.; Viola, M.; Russo, G.; Prezzavento, O.; Marrazzo, A.; Amata, E.; Reibaldi, M.; 
Longo, A.; Russo, A.; Parrinello, N. L.; Volti, G. L. Sigma-1 and Sigma-2 receptor ligands induce apoptosis and autophagy but have opposite effect on cell proliferation in uveal melanoma. Oncotarget 2017, 8, 91099-91111.

(21) Cusack, B.; Nelson, A.; Richelson, E. Binding of antidepressants to human brain receptors: focus on newer generation compounds. Psychopharmacology 1994, 114, 559-565.

(22) Li, Z.; Zhu, W. G. Targeting histone deacetylases for cancer therapy: from molecular mechanisms to clinical implications. Int. J. Biol. Sci. 2014, 10, 757-770.

(23) Halsall, J.; Gupta, V.; O’Neill, L. P.; Turner, B. M.; Nightingale, K. P. Genes are often sheltered from the global histone hyperacetylation induced by HDAC inhibitors. PLoS One 2012, 7, No. e33453.

(24) Damaskos, C.; Karatzas, T.; Nikolidakis, L.; Kostakis, I. D.; Karamaroudis, S.; Boutsikos, G.; Damaskou, Z.; Kostakis, A.; Kouraklis, G. Histone Deacetylase (HDAC) Inhibitors: Current Evidence for Therapeutic Activities in Pancreatic Cancer. Anticancer Res. 2015, 35, 3129-3135.

(25) Deng, B.; Luo, Q.; Halim, A.; Liu, Q.; Zhang, B.; Song, G. The antiangiogenesis role of histone deacetylase inhibitors: their potential application to tumor therapy and tissue repair. DNA Cell Biol. 2020, $39,167-176$.

(26) Mann, B. S.; Johnson, J. R.; He, K.; Sridhara, R.; Abraham, S.; Booth, B. P.; Verbois, L.; Morse, D. E.; Jee, J. M.; Pope, S.; Harapanhalli, R. S.; Dagher, R.; Farrell, A.; Justice, R.; Pazdur, R. Vorinostat for treatment of cutaneous manifestations of advanced primary cutaneous T-cell lymphoma. Clin. Cancer Res. 2007, 13, 2318-22.

(27) Prince, H. M.; Dickinson, M. Romidepsin for cutaneous T-cell lymphoma. Clin. Cancer Res. 2012, 18, 3509-15.

(28) Landreville, S.; Agapova, O. A.; Matatall, K. A.; Kneass, Z. T.; Onken, M. D.; Lee, R. S.; Bowcock, A. M.; Harbour, J. W. Histone deacetylase inhibitors induce growth arrest and differentiation in uveal melanoma. Clin. Cancer Res. 2012, 18, 408-416.

(29) Landreville, S.; Agapova, O. A.; Matatall, K. A.; Kneass, Z. T.; Onken, M. D.; Lee, R. S.; Bowcock, A. M.; Harbour, J. W. Histone deacetylase inhibitors induce growth arrest and differentiation in uveal melanoma. Clin. Cancer Res. 2012, 18, 408-416.

(30) Sato, T.; Orloff, M. M.; Valsecchi, M. E.; Shimada, A.; Chervoneva, I.; Sharpe-Mills, E.; Klose, H.; Norcini, J.; Belinsky, J.; Sato, S.; Hulse, L.; Shields, C. L.; Shields, J. A.; Mastrangelo, M. J. A randomized phase II study of adjuvant sunitinib or valproic acid in high-risk patients with uveal melanoma. J. Clin. Oncol. 2020, 38, No. e22059.

(31) Tan, J.; Cang, S.; Ma, Y.; Petrillo, R. L.; Liu, D. Novel histone deacetylase inhibitors in clinical trials as anti-cancer agents. J. Hematol. Oncol. 2010, 3, No. 5.

(32) Marrazzo, A.; Fiorito, J.; Zappala, L.; Prezzavento, O.; Ronsisvalle, S.; Pasquinucci, L.; Scoto, G. M.; Bernardini, R.; Ronsisvalle, G. Antiproliferative activity of phenylbutyrate ester of haloperidol metabolite II [(+/-)-MRJF4] in prostate cancer cells. Eur. J. Med. Chem. 2011, 46, 433-438.

(33) Sozio, P.; Fiorito, J.; Di Giacomo, V.; Di Stefano, A.; Marinelli, L.; Cacciatore, I.; Cataldi, A.; Pacella, S.; Turkez, H.; Parenti, C.; Rescifina, A.; Marrazzo, A. Haloperidol metabolite II prodrug: asymmetric synthesis and biological evaluation on rat C6 glioma cells. Eur. J. Med. Chem. 2015, 90, 1-9.

(34) Olivieri, M.; Amata, E.; Vinciguerra, S.; Fiorito, J.; Giurdanella, G.; Drago, F.; Caporarello, N.; Prezzavento, O.; Arena, E.; Salerno, L.; Rescifina, A.; Lupo, G.; Anfuso, C. D.; Marrazzo, A. Antiangiogenic Effect of (+/-)-Haloperidol Metabolite II Valproate Ester [(+/-)-MRJF22] in Human Microvascular Retinal Endothelial Cells. J. Med. Chem. 2016, 59, 9960-9966.

(35) Logan, P.; Burnier, J.; Burnier, M. N., Jr. Vascular endothelial growth factor expression and inhibition in uveal melanoma cell lines. Ecancermedicalscience 2013, 7, No. 336.

(36) Missotten, G. S. O.; Notting, I. C.; Schlingemann, R. O.; Zijlmans, H. J.; Lau, C.; Eilers, P. H. C.; Keunen, J. E. E.; Jager, M. J.
Vascular Endothelial Growth Factor A in Eyes With Uveal Melanoma. Arch. Ophthalmol. 2006, 124, 1428-1434.

(37) Jaen, J. C.; C, B. W.; Priebe, S.; Wise, L. D. Synthesis of the enantiomers of reduced haloperidol. Pharm. Res. 1991, 8, 1002-1005.

(38) Liederer, B. M.; Borchardt, R. T. Enzymes involved in the bioconversion of ester-based prodrugs. J. Pharm. Sci. 2006, 95, 117795.

(39) Walker, J. M.; Bowen, W. D.; Walker, F. O.; Matsumoto, R. R.; De Costa, B.; Rice, K. C. Sigma receptors: biology and function. Pharmacol. Rev. 1990, 42, 355-402.

(40) Kashyap, M. V.; Ranjan, A. P.; Shankardas, J.; Vishwanatha, J. K. Establishment of human retinal microvascular endothelial cells with extended life-span. In Vivo 2013, 27, 685-694.

(41) Bao, P.; Kodra, A.; Tomic-Canic, M.; Golinko, M. S.; Ehrlich, H. P.; Brem, H. The role of vascular endothelial growth factor in wound healing. J. Surg. Res. 2009, 153, 347-58.

(42) Seftor, E. A.; Meltzer, P. S.; Kirschmann, D. A.; Pe'er, J.; Maniotis, A. J.; Trent, J. M.; Folberg, R.; Hendrix, M. J. C. Molecular determinants of human uveal melanoma invasion and metastasis. Clin. Exp. Metastasis 2002, 19, 233-246.

(43) Levinzon, L.; Madigan, M.; Nguyen, V.; Hasic, E.; Conway, M.; Cherepanoff, S. Tumour expression of histone deacetylases in uveal melanoma. Ocul. Oncol. Pathol. 2019, 5, 153-161.

(44) Chen, J.; Ghazawi, F. M.; Bakkar, W.; Li, Q. Valproic acid and butyrate induce apoptosis in human cancer cells through inhibition of gene expression of Akt/protein kinase B. Mol. Cancer 2006, 5, No. 71.

(45) Rossi, M.; Petralla, S.; Protti, M.; Baiula, M.; Kobrlova, T.; Soukup, O.; Spampinato, S. M.; Mercolini, L.; Monti, B.; Bolognesi, M. L. Alpha-linolenic acid-valproic acid conjugates: toward singlemolecule polypharmacology for multiple sclerosis. ACS Med. Chem. Lett. 2020, 11, 2406-2413.

(46) Mach, R. H.; Smith, C. R.; Childers, S. R. Ibogaine possesses a selective affinity for sigma 2 receptors. Life Sci 1995, 57, PL57-PL62.

(47) Matsumoto, R. R.; Bowen, W. D.; Tom, M. A.; Vo, V. N.; Truong, D. D.; De Costa, B. R. Characterization of two novel sigma receptor ligands: antidystonic effects in rats suggest sigma receptor antagonism. Eur. J. Pharmacol. 1995, 280, 301-310.

(48) Anfuso, C. D.; Longo, A.; Distefano, A.; Amorini, A. M.; Salmeri, M.; Zanghi, G.; Giallongo, C.; Giurdanella, G.; Lupo, G. Uveal Melanoma Cells Elicit Retinal Pericyte Phenotypical and Biochemical Changes in an in Vitro Model of Coculture. Int. J. Mol. Sci. 2020, 21, No. 5557 .

(49) Albertson, N. F.; Wetterau, W. F. The synthesis of pentazocine. J. Med. Chem. 1970, 13, 302-303.

(50) Maeda, D. Y.; Williams, W.; Kim, W. E.; Thatcher, L. N.; Bowen, W. D.; Coop, A. N-Arylalkylpiperidines as High-Affinity Sigma-1 and Sigma-2 Receptor Ligands: Phenylpropylamines as Potential Leads for Selective Sigma-2 Agents. Bioorg. Med. Chem. Lett. 2002, 12, 497-500. 